\title{
Counter-ion effect on antistaphylococcal activity and cytotoxicity of selected antimicrobial peptides
}

\author{
Karol Sikora ${ }^{1}$ [ $\cdot$ Maciej Jaśkiewicz ${ }^{1}$. Damian Neubauer ${ }^{1}$. Marta Bauer ${ }^{1} \cdot$ Sylwia Bartoszewska ${ }^{1}$. \\ Wioletta Barańska-Rybak ${ }^{2}$. Wojciech Kamysz ${ }^{1}$
}

Received: 25 November 2017 / Accepted: 28 December 2017 / Published online: 6 January 2018

(C) The Author(s) 2018. This article is an open access publication

\begin{abstract}
In view of an appreciable increase in resistance of Staphylococcus aureus to the conventional antibiotics, it is desired to develop new effective drugs. Antimicrobial peptides (AMPs) seem to be attractive candidates. In general, AMPs samples used for in vitro studies consist of a peptide, counter-ion, and water. The presence of the counter-ion could be significant as it affects peptide secondary structure and biological activity. The purpose of this study was to estimate the impact of counter-ion on antistaphylococcal activity of selected AMPs (CAMEL, citropin 1.1, LL-37, pexiganan, temporin A). To do this, three kinds of salts were prepared, namely, acetates, hydrochlorides, and trifluoroacetates. In addition, the hemolytic activity against human red blood cells (hRBCs) and cytotoxicity (HaCaT) were determined. The results indicate that there is a substantial difference between different salts, but the pattern is not consistent for the peptides. In general, the antistaphylococcal activity decreased in the order: CAMEL $>$ temporin $\mathrm{A}>$ pexiganan $>$ citropin $1.1 \gg$ LL-37. The highest selectivity indexes were determined for CAMEL hydrochloride, pexiganan acetate, and temporin A trifluoroacetate. This study shows how important is to take into account the kind of counter-ions when designing novel peptide-based antimicrobials.
\end{abstract}

Keywords Counter-ion · Antistaphylococcal activity · Antimicrobial peptides · CAMEL · Citropin 1.1 · LL-37 · Pexiganan · Temporin A

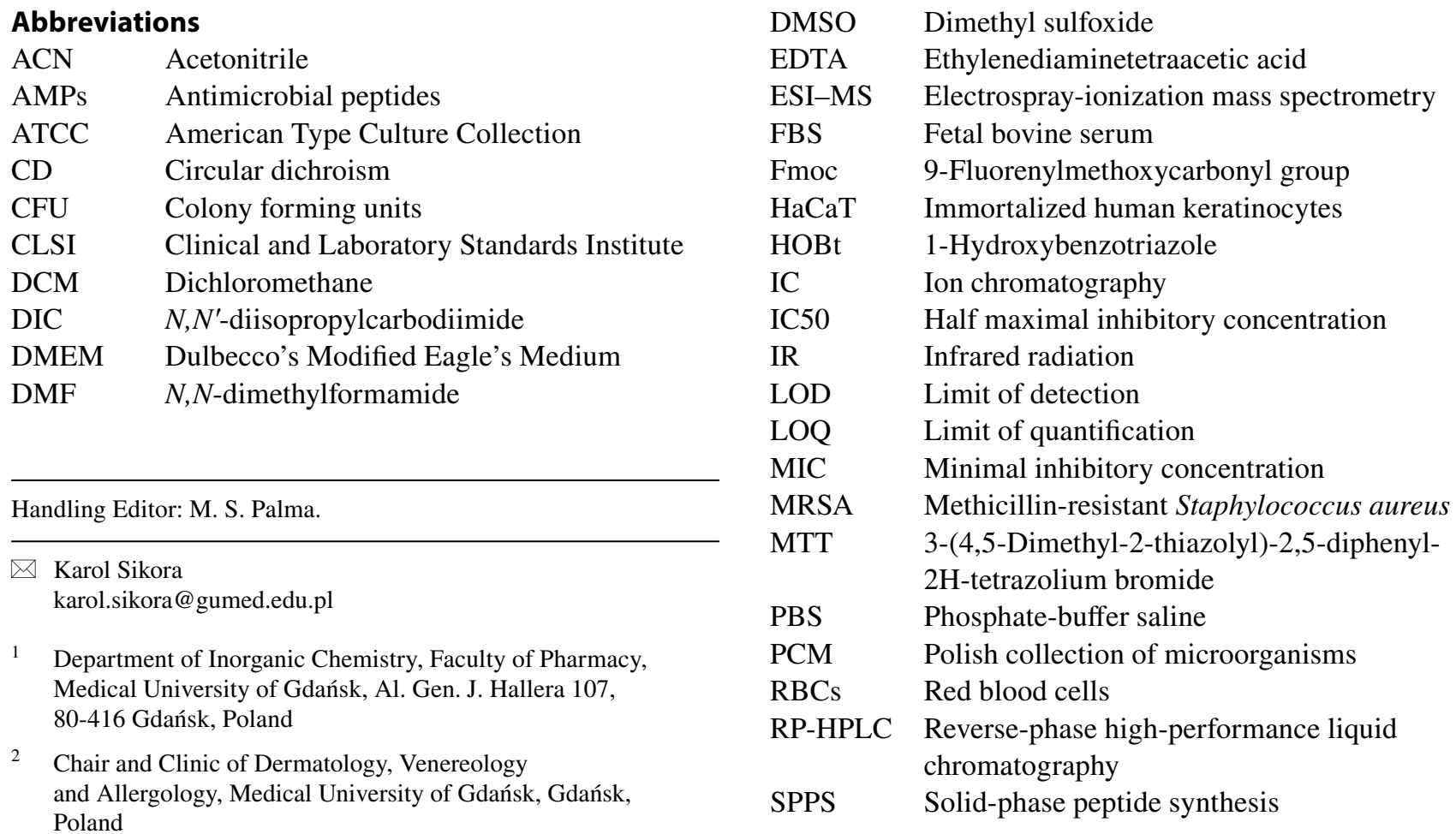


TFA Trifluoroacetic acid

TIS Triisopropylsilane

\section{Introduction}

Nowadays, the solid-phase synthesis is a popular method in organic chemistry, especially in peptide synthesis (SPPS). Since 1963, when solid-phase method had been introduced by Merrifield, a lot of effort has been expended on SPPS development. Nonetheless, the main features of the method remained unchanged. In general, amino acid derivatives are subsequently attached to an elongated peptide chain and the product is released from the resin with a strong acid. The most popular is Fmoc/tert-butyl chemistry where trifluoroacetic acid (TFA) is used for cleavage and final deprotection. Moreover, it is used in RP-HPLC as an additive to mobile phase, e.g., for ion-pairing of basic side chains and $N$-terminus amino group (Chandrudu et al. 2013; Mäde et al. 2014). In effect, synthetic peptides purified by RP-HPLC are obtained as trifluoroacetate salts. Moreover, an excess of the trifluoroacetate ion (together with those anions that are directly bound to positively charged groups) in peptides' lyophilizate may occur. Importantly, TFA anions are able to affect both the biological and physico-chemical properties of peptides, and for this reason, it is important to consider the counter-ions in peptide studies, including in vivo experiments. To date, several reports regarding the TFA toxicity against cells, e.g., suppression of proliferation of osteoblasts, were reported (Cornish et al. 1999). In fact, counter-ions may also affect the secondary structure of peptides and proteins (Gaussier et al. 2002). The presence of different counter-ions can affect hydrogen-bonding network and alter its structure (Blondelle et al. 1995) (Cinelli et al. 2001). Characterization of synthetic peptides, including conformational analysis, is routinely performed using IR and CD spectroscopy. However, a strong IR band at around $1670 \mathrm{~cm}^{-1}$ assigned to TFA which overlaps the amide I band of peptides $\left(1600-1700 \mathrm{~cm}^{-1}\right.$ ) may complicate analysis (Gaussier et al. 2002). Several methods of peptide $\mathrm{TFA}^{-}$counter-ion exchange are described in the literature. A popular one utilizes lyophilization from aqueous solutions of a strong acid, e.g., hydrochloric. As a matter of fact, this method is limited to those anions of acids that are stronger than TFA (with lower $\mathrm{pK}_{\mathrm{a}}$ values). Other counter-ion exchange methods are based on RP-HPLC, anion-exchange resins, and dialysis through membranes (Roux et al. 2008). Despite the documented influence of counter-ions on the structure and biological activity of molecules, studies on antimicrobial peptides (AMPs) in this area are rather sparse. Nevertheless, the counter-ion effect cannot be ignored, especially because AMPs are positively charged and can interact with anions such as trifluoroacetates. Antimicrobial peptides (AMPs) are the group of compounds that seem to be an alternative to the conventional antibiotics. These evolutionally conserved molecules play a vital role in the innate immune systems of almost all organisms (Mansour et al. 2014). They are targeting a broad spectrum of organisms including bacteria, fungi, protozoa, and viruses, and are able to trigger and coordinate multiple components of innate immunity. For this reason, much attention has been paid to the design of novel, synthetic AMPs (de novo design) with improved properties. A substantial number of AMPs exhibit the antistaphylococcal activity that makes them an object of intense research (Dawgul et al. 2016; Mohamed et al. 2016). Since Staphylococcus aureus is still one of the leading pathogens associated with nosocomial and wound infections, it is desired to develop new effective therapies. The aim of this study was to investigate the effect of counter-ion type on antistaphylococcal activity and cytotoxicity of selected AMPs. Peptides used in this study were, CAMEL (Andreu et al. 1992), citropin 1.1 (Wegener et al. 1999), LL-37 (Larrick et al. 1995), pexiganan (Ge et al. 1999), and temporin A (Simmaco et al. 1996). For estimation of the influence of different counter-ions on antistaphylococcal activity, the trifluoroacetate, acetate, and chloride salts were prepared.

\section{Methods}

\section{Peptide synthesis, purification, and analysis}

The tested peptides (cf. Table 1) were synthesized manually by solid-phase method using Fmoc chemistry on the Rink amide or Wang resin (Fields and Noble 1990). All reactions were run using a CEM microwave synthesizer (Liberty Blue) to provide an enhanced efficiency as compared to that obtained by the conventional methodology (Rizzolo et al. 2011). Coupling reaction was carried out by activation with DIC ( $N, N^{\prime}$-diisopropylcarbodiimide) in DMF $(N, N$ dimethylformamide). OxymaPure was applied to suppress racemization instead of $\mathrm{HOBt}$ owing to superior coupling efficiencies (Subirós-Funosas et al. 2009). Single deprotection step was accomplished in a $20 \%$ piperidine solution in DMF. Deprotection was performed at $75{ }^{\circ} \mathrm{C}$ using $30 \mathrm{~W}$ for 3 min, whereas the coupling steps were performed at $75{ }^{\circ} \mathrm{C}$ using $30 \mathrm{~W}$ for $5 \mathrm{~min}$. All reagents were used in a fourfold excess based on the resin. A mixture of TFA, TIS (triisopropylsilane), phenol, and water (92.5:2.5:2.5:2.5, v/v) was used to cleave a peptide from the resin. This reaction was accomplished for 90 min under stirring. The crude peptide was lyophilized and subsequently purified by RP-HPLC. Purifications were carried out on a Phenomenex GeminiNX C18 column $(21.20 \times 100 \mathrm{~mm}, 5.0 \mu \mathrm{m}$ particle size, and $110 \AA$ pore size). UV detection at $214 \mathrm{~nm}$ was used, and the crude peptides were eluted with a linear $10-70 \%$ 
Table 1 Peptides used in this study

\begin{tabular}{|c|c|c|c|c|c|c|}
\hline \multirow[t]{2}{*}{ Peptide } & \multirow[t]{2}{*}{ Sequence } & \multirow[t]{2}{*}{ Net charge } & \multirow{2}{*}{$\begin{array}{l}\text { Average } \\
\text { mass (Da) }\end{array}$} & \multicolumn{3}{|c|}{ MS analysis } \\
\hline & & & & $z^{\mathrm{a}}$ & $m / z^{\mathrm{b}}$ & $m / z^{\mathrm{c}}$ \\
\hline \multirow[t]{3}{*}{ CAMEL } & \multirow[t]{3}{*}{ KWKLFKKIGAVLKVL-NH ${ }_{2}$} & \multirow[t]{3}{*}{+6} & \multirow[t]{3}{*}{1771.31} & 2 & 886.17 & 886.85 \\
\hline & & & & 3 & 591.12 & 591.27 \\
\hline & & & & 4 & 444.59 & 444.89 \\
\hline \multirow[t]{2}{*}{ Citropin 1.1} & \multirow[t]{2}{*}{ GLFDVIKKVASVIGGL-NH ${ }_{2}$} & \multirow[t]{2}{*}{+2} & \multirow[t]{2}{*}{1614.99} & 2 & 809.50 & 808.41 \\
\hline & & & & 3 & 539.34 & 539.37 \\
\hline \multirow[t]{5}{*}{ LL-37 } & \multirow{5}{*}{$\begin{array}{l}\text { LLGDFFRKSKEKIGKEFKRIVQRIKD- } \\
\text { FLRNLVPRTES }\end{array}$} & \multirow[t]{5}{*}{+6} & \multirow[t]{5}{*}{4493.33} & 4 & 1124.34 & 1124.31 \\
\hline & & & & 5 & 899.67 & 899.68 \\
\hline & & & & 6 & 749.90 & 750.08 \\
\hline & & & & 7 & 642.91 & 643.19 \\
\hline & & & & 8 & 562.67 & 562.78 \\
\hline \multirow[t]{5}{*}{ Pexiganan } & \multirow[t]{5}{*}{ GIGKFLKKAKKFGKAFVKILKK-NH ${ }_{2}$} & \multirow[t]{5}{*}{+10} & \multirow[t]{5}{*}{2477.21} & 2 & 1239.61 & 1239.39 \\
\hline & & & & 3 & 826.75 & 826.71 \\
\hline & & & & 4 & 620.31 & 620.34 \\
\hline & & & & 5 & 496.45 & 496.52 \\
\hline & & & & 6 & 413.88 & 414.11 \\
\hline Temporin A & FLPLIGRVLSGIL-NH ${ }_{2}$ & +2 & 1396.78 & 2 & 699.40 & 699.33 \\
\hline
\end{tabular}

$a$ Ion charge, $b$ calculated mass-to-charge ratio, $c$ measured mass-to-charge ratio acetonitrile gradient in deionized water over $90 \mathrm{~min}$ at room temperature. The mobile phase flow rate was $10.0 \mathrm{~mL} / \mathrm{min}$. Acetonitrile and water, both containing $0.1 \%$ of TFA, were used as a mobile phase. The purity and identity of the peptide was confirmed by the LC-MS analysis. RP-HPLC system was used-Waters Alliance e2695 system with Waters 2998 PDA and Acquity QDA detectors (software-Empower ${ }^{\circledR} 3$ ). All analyses were carried out on a Waters XBridge ${ }^{\text {TM }}$ Shield RP-18 column $(4.6 \times 150 \mathrm{~mm}, 3.5 \mu \mathrm{m}$ particle size, 130 $\AA$ pore size). Samples $(10 \mu \mathrm{L})$ were analyzed with a linear 10-90\% acetonitrile gradient in deionized water over $15 \mathrm{~min}$ at $25.0 \pm 0.1{ }^{\circ} \mathrm{C}$. The mobile phase flow rate was $0.5 \mathrm{~mL} / \mathrm{min}$. Both eluents contained $0.1 \%(\mathrm{v} / \mathrm{v})$ of formic acid. Mass analysis and UV detection at $214 \mathrm{~nm}$ were used. Pure fractions (>95\%, by HPLC analysis) were collected and lyophilized.

\section{lon chromatography and counter-ion exchange}

Initially, all peptides were obtained as TFA salts. Counter-ions were then exchanged to biocompatible ones: acetates $\left(\mathrm{AcO}^{-}\right)$ and hydrochlorides $\left(\mathrm{Cl}^{-}\right)$. Exchange to $\mathrm{AcO}^{-}$was accomplished in two steps. First, TFA anions were removed with a carbonate ion-exchange resin (Agilent, VariPure columns). Subsequently, the diluted acetic acid was added and the samples were lyophilized. The exchange to $\mathrm{Cl}^{-}$was performed with commonly used method which utilizes the lyophilization from 0.1 M HCl solution (Andrushchenko et al. 2007) or using a HCl-saturated acetonitrile as reported elsewhere (Sikora et al. 2017). With water solutions, exchange was repeated four times and the final products were lyophilized from deionized water to remove an excess of the acid. With saturated acetonitrile, the exchange was repeated twice. Determination of counter-ions and their quantification was done using ion chromatography (Dionex ICS-5000+, ThermoScientific). The method was validated for the analysis of $\mathrm{TFA}^{-}, \mathrm{AcO}^{-}$, and $\mathrm{Cl}^{-}$according to the $\mathrm{ICH}$ guidelines Q2 (R1) (ICH 2005). The analyses were performed with isocratic elution (4.5 mM Na $\mathrm{CO}_{3}$ and $1.4 \mathrm{mM} \mathrm{NaHCO}_{3}$ in water), a flow rate of $1.2 \mathrm{~mL} / \mathrm{min}$, and the injection volume of $20 \mu \mathrm{L}$. All the tested samples were dissolved in water to obtain a concentration of $0.5 \mathrm{mg} / \mathrm{mL}$. Ions were detected by suppressed conductivity with ASRS 300 - anion self-regenerating suppressor and the suppressor current of $31 \mathrm{~mA}$. Column characteristics-Dionex IonPac AS22, dimensions $4.0 \times 250 \mathrm{~mm}$. Column compartment temperature was set at $30 \pm 0.1^{\circ} \mathrm{C}$ and conductivity detector temperature was $35 \pm 0.1{ }^{\circ} \mathrm{C}$.

\section{Peptide content}

The peptide content was determined spectrophotometrically and the absorbance was measured at $214 \mathrm{~nm}$ (Multiskan ${ }^{\mathrm{TM}}$ GO Microplate Spectrophotometer, Thermo Scientific). For this purpose, different concentrations of the peptide salts were applied, namely $0.025,0.050,0.075$, and $0.100 \mathrm{mg} /$ $\mathrm{mL}$ to provide evidence that the measurements were accomplished within the linearity range. All samples were dissolved in deionized water and the measurements were conducted in a quartz cuvette with a $10 \mathrm{~mm}$ path length. The calculations were done as presented below (Eq. 1):

Milligram of peptide per milliliter $=\left(A_{\lambda} \times \mathrm{DF} \times \mathrm{MW}\right) / e$ 
where $\mathrm{A}_{214}$-absorbtion at $214 \mathrm{~nm}$ [AU], DF-dilution factor, MW-peptide molecular weight $\left[\mathrm{mg} \times \mathrm{mmole}^{-1}\right]$, and $\mathrm{e}-$ molar extinction coefficient at $214 \mathrm{~nm}\left[\mathrm{~cm}^{-1} \times \mathrm{M}^{-1}\right]$.

\section{Organisms and microbiological assay}

Microbiological assays were performed using reference and clinical strains of Staphylococcus aureus. Minimal inhibitory concentrations (MIC) were determined by broth microdilution method on 96-well polystyrene plates according to Clinical and Laboratory Standards Institute (CLSI) recommendations [Clinical and Laboratory Standards Institute (CLSI) 2012]. For this purpose, the initial inoculums of $0.5 \times 10^{5} \mathrm{CFU} / \mathrm{mL}$ of bacteria were exposed to a range of concentrations of the peptides $(0.5-256 \mu \mathrm{g} / \mathrm{mL})$. All plates were incubated for $18 \mathrm{~h}$ at $37^{\circ} \mathrm{C}$. MIC was taken as the lowest concentration of the compound at which the growth of bacteria was not observed. Reference strains of $S$. aureus: ATCC 6538, ATCC 6538/P, ATCC 9144, ATCC 12598, and ATCC 25923 were obtained from the Polish Collection of Microorganisms (PCM, Polish Academy of Sciences, Wrocław), whereas 24 clinical strains were isolated from the patients of the Clinic of Dermatology, Venereology and Allergology (Medical University of Gdańsk). Nine strains were characterized as methicillin-resistant (MRSA). Preliminary identification and detection was conducted on the ChromID MRSA/ChromID S. aureus biplate (bioMérieux) for the simultaneous detection of $S$. aureus and methicillin-resistant S. aureus (MRSA). All experiments were conducted at least in triplicate.

\section{Hemolysis assay}

The hemolysis assay was conducted using a procedure described in the literature (Avrahami and Shai 2004). Fresh human red blood cells (RBCs) with EDTA as anticoagulant were rinsed three times with phosphate-buffer saline (PBS) by centrifugation at $800 \times \mathrm{g}$ for $10 \mathrm{~min}$ and resuspended in PBS. Serial dilution of peptides $(1-512 \mu \mathrm{g} / \mathrm{mL})$ was conducted in PBS on 96-well plates. Then, the stock solution of RBCs was added to reach a final volume of $100 \mu \mathrm{L}$ with $4 \%$ concentration of erythrocytes (v/v). The control wells for $0 \%$ hemolysis and $100 \%$ hemolysis consisted of RBCs suspended in PBS and $1 \%$ of Triton X-100, respectively. Subsequently, the plates were incubated for $60 \mathrm{~min}$ at $37^{\circ} \mathrm{C}$ and then centrifuged at $800 \times \mathrm{g}$ for $10 \mathrm{~min}$ at $4{ }^{\circ} \mathrm{C}$ (Sorvall ST 16R Centrifuge, Thermo Scientific). After centrifugation, the supernatant was carefully resuspended to new microtiter plates and the release of hemoglobin was monitored by measurement of absorbance at $540 \mathrm{~nm}$ (Multiskan ${ }^{\mathrm{TM}} \mathrm{GO}$ Microplate Spectrophotometer, Thermo Scientific). All experiments were conducted in triplicate.

\section{MTT assay}

To assess the cytotoxicity of the compounds (IC50), the classic MTT assay on 96-well plates was performed for human keratinocytes (HaCaT) obtained from the ATCC. The assay utilizes a colorimetric determination of cell metabolic activity. The color intensity reflects the number of live cells and can be measured spectrophotometrically. Cell line was cultured in DMEM supplemented with 10\% FBS (v/v), 100 units $/ \mathrm{mL}$ of penicillin, $100 \mu \mathrm{g} / \mathrm{mL}$ of streptomycin, and $2 \mathrm{mM} \mathrm{L}$-glutamine, and were kept at $37{ }^{\circ} \mathrm{C}$ in a humidified $5 \% \mathrm{CO}_{2}$ incubator. Briefly, a day after plating of 500 cells per well, different concentrations of the tested compounds were applied $(0.5-500 \mu \mathrm{g} / \mathrm{mL})$. DMSO was added to the control cells at a final concentration of $1.0 \%$ $(\mathrm{v} / \mathrm{v})$, which was related to the maximal concentration of the solvent compounds used in the experiment. After $24 \mathrm{~h}$ of incubation at $37{ }^{\circ} \mathrm{C}$ (humidified $5 \% \mathrm{CO}_{2}$ incubator) with the specified compounds, a medium containing $1 \mathrm{mg} / \mathrm{mL}$ of MTT was added to wells to reach a final concentration of $0.5 \mathrm{mg} / \mathrm{mL}$. Subsequently, the plates were incubated at $37^{\circ} \mathrm{C}$ for $4 \mathrm{~h}$. Then, the medium was aspirated, and the formazan product was solubilized with DMSO. The absorbance at $630 \mathrm{~nm}$ (background absorbance) was subtracted from that at $570 \mathrm{~nm}$ for each well (Epoch, BioTek Instruments, USA). Six replicates were conducted for each concentration. All experiments were repeated at least twice and the resulting IC50 values were calculated with a GraFit 7 software.

\section{Results and discussion}

\section{Peptides synthesis}

Information about peptides sequence, net charge, average mass, and the results of the MS analysis are presented in Table 1.

\section{Counter-ion exchange and determination of counter-ion content}

Initially, all peptides were obtained as trifluoroacetate salts and the amount of counter-ions was determined by IC. The level of TFA ${ }^{-}$ranged between 150 and $320 \mu \mathrm{g}$ per $1 \mathrm{mg}$ of peptide sample. Moreover, no other anions were detected. Replacement of trifluoroacetates by chlorides was achieved and the level of $\mathrm{Cl}^{-}$anions was above $97 \mathrm{~mol} \%$ for all peptides. After conversion to chlorides, small amounts of $\mathrm{TFA}^{-}$were found, but further lyophilization from hydrochloric acid did not result in its total elimination. Consistency of all peptides after the exchange was proved by LC-MS analysis. Nonetheless, in case of LL-37, the conversion to chlorides resulted in a lower stability of the peptide. At the 
beginning, a $0.1 \mathrm{M}$ hydrochloric acid was used. To overcome this problem, we applied an alternative way using $\mathrm{HCl}$-saturated acetonitrile as described elsewhere (Sikora et al. 2017). This modified procedure provided satisfactory conversion to chlorides without peptide degradation. Nevertheless, the stability of the LL-37 chloride turned out to be lower than that of trifluoroacetate and acetate salts, and a slow hydrolysis of the peptide in both the aqueous solution and lyophilizate occurred. This finding suggests that LL-37 hydrochloride inadequate for prolonged storage. In the case of the majority of acetate salts, the level of other anions $\left(\mathrm{TFA}^{-}\right.$and $\mathrm{Cl}^{-}$) was below the limit of detection (LOD) or the limit of quantification (LOQ). Only in samples of temporin A and pexiganan, traces of chlorides were detected. Probably, the chloride as an impurity of the VariPure columns might be bound to the peptides during TFA removal. Results of IC analysis are summarized in Table 2.

\section{Peptide content}

The content of the peptides was determined by measurement of absorbance at $214 \mathrm{~nm}$. Their molar extinction coefficients were calculated using appropriate coefficients of peptide building blocks (Kuipers and Gruppen 2007). The results of calculations are summarized in Table 3 .

The content of the peptides in lyophilizates was calculated for different dilutions within linearity range $(0.025-0.1 \mathrm{mg} /$ $\mathrm{mL}$ ). In Table 4, mean values of the calculated mass fraction, relative standard deviations and relative (percentage) contents are presented. Relative concentration was calculated based on the $\mathrm{TFA}^{-}$salt assumed as $100 \%$. Relative

Table 2 Counter-ions content in peptides ( $\mu \mathrm{g} / \mathrm{mg}$ and $\% \mathrm{~mol}$ )

\begin{tabular}{|c|c|c|c|c|}
\hline Peptide & $\begin{array}{l}\text { Desired } \\
\text { counter- } \\
\text { ion }\end{array}$ & $\mathrm{TFA}^{-}$ & $\mathrm{AcO}^{-}$ & $\mathrm{Cl}^{-}$ \\
\hline \multirow[t]{3}{*}{ CAMEL } & $\mathrm{TFA}^{-}$ & $272.32 / 100 \%$ & $<$ LOD & $<\mathrm{LOQ}$ \\
\hline & $\mathrm{AcO}^{-}$ & $<\mathrm{LOQ}$ & $146.62 / 98 \%$ & $3.22 / 2 \%$ \\
\hline & $\mathrm{Cl}^{-}$ & $6.67 / 2 \%$ & $<\mathrm{LOD}$ & $98.15 / 98 \%$ \\
\hline \multirow[t]{3}{*}{ Citropin 1.1} & $\mathrm{TFA}^{-}$ & $186.32 / 100 \%$ & $<$ LOQ & $<\mathrm{LOQ}$ \\
\hline & $\mathrm{AcO}^{-}$ & $<\mathrm{LOQ}$ & $57.76 / 100 \%$ & $<\mathrm{LOQ}$ \\
\hline & $\mathrm{Cl}^{-}$ & $6.42 / 3 \%$ & $<$ LOD & $69.41 / 97 \%$ \\
\hline \multirow[t]{3}{*}{ LL-37 } & $\mathrm{TFA}^{-}$ & $155.82 / 100 \%$ & $<$ LOD & $<\mathrm{LOD}$ \\
\hline & $\mathrm{AcO}^{-}$ & $<$LOQ & $157.52 / 100 \%$ & $<$ LOQ \\
\hline & $\mathrm{Cl}^{-}$ & $2.30 / 2 \%$ & $<\mathrm{LOQ}$ & $177.56 / 98 \%$ \\
\hline \multirow[t]{3}{*}{ Pexiganan } & $\mathrm{TFA}^{-}$ & $317.94 / 100 \%$ & $<$ LOD & $<\mathrm{LOQ}$ \\
\hline & $\mathrm{AcO}^{-}$ & $<\mathrm{LOQ}$ & $282.43 / 98 \%$ & $2.52 / 2 \%$ \\
\hline & $\mathrm{Cl}^{-}$ & $5.06 / 1 \%$ & $<\mathrm{LOD}$ & $114.09 / 99 \%$ \\
\hline \multirow[t]{3}{*}{ Temporin A } & $\mathrm{TFA}^{-}$ & $162.54 / 100 \%$ & $<\mathrm{LOD}$ & $<\mathrm{LOQ}$ \\
\hline & $\mathrm{AcO}^{-}$ & $<$LOQ & $63.8 / 94 \%$ & $2.47 / 6 \%$ \\
\hline & $\mathrm{Cl}^{-}$ & $4.73 / 3 \%$ & $<$ LOD & $49.28 / 97 \%$ \\
\hline
\end{tabular}

Table 3 Molar extinction coefficients of the peptides

\begin{tabular}{ll}
\hline Peptide & $\begin{array}{l}\text { Molar extinction coefficient } \\
\text { at } 214 \mathrm{~nm}\left[\mathrm{~cm}^{-1} \times \mathrm{M}^{-1}\right]\end{array}$ \\
\hline CAMEL & 47,653 \\
Citropin 1.1 & 19,623 \\
LL-37 & 55,919 \\
Pexiganan & 35,702 \\
Temporin A & 19,442 \\
\hline
\end{tabular}

concentration of 2 other salts was calculated on this basis. Moreover, the influence of counter-ions on absorbance was evaluated. Despite the fact that trifluoroacetate has the highest molar extinction coefficient, the absorbance, even at a concentration of $0.1 \mathrm{mg} / \mathrm{mL}$, was insignificant $(0.016 \mathrm{AU})$.

It should be mentioned that molar extinction coefficients are strongly affected by peptide sequence and conformation. Calculation of molar extinction coefficients by adding up extinction coefficients of amino acids and peptide bonds are charged with an error. Consequently, calculation of absolute peptide content cannot be done by measurement of absorbance at $214 \mathrm{~nm}$. Nevertheless, this procedure can be used to compare the content of a particular peptide with different counter-ions. For all peptides, the calculated concentrations ranged from 0.60 to $0.75 \mathrm{mg} / \mathrm{mg}$ of lyophilizate. Surprisingly, the high content of the peptide was found for temporin A. Probably, this can be explained in terms of an overestimated value of molar extinction coefficient.

More information could be extracted by comparison of relative concentrations. In relation to $\mathrm{TFA}^{-}$salts, the

Table 4 Peptide content and relative peptide content in peptides' salts

\begin{tabular}{lllll}
\hline Peptide & Counter-ion & $\begin{array}{l}\text { Mass frac- } \\
\text { tion (mg/ } \\
\text { mg) }\end{array}$ & RSD (\%) & Relative content \\
\hline CAMEL & $\mathrm{TFA}^{-}$ & 0.662 & 1.3 & $100 \%$ \\
& $\mathrm{AcO}^{-}$ & 0.705 & 3.1 & $106.5 \%$ \\
& $\mathrm{Cl}^{-}$ & 0.624 & 1.2 & $94.2 \%$ \\
Citropin 1.1 & $\mathrm{TFA}^{-}$ & 0.703 & 3.0 & $100 \%$ \\
& $\mathrm{AcO}^{-}$ & 0.774 & 0.3 & $110.1 \%$ \\
& $\mathrm{Cl}^{-}$ & 0.798 & 1.5 & $113.5 \%$ \\
LL-37 & $\mathrm{TFA}^{-}$ & 0.719 & 3.8 & $100 \%$ \\
& $\mathrm{AcO}^{-}$ & 0.791 & 2.7 & $110.1 \%$ \\
& $\mathrm{Cl}^{-}$ & 0.857 & 1.4 & $119.2 \%$ \\
Pexiganan & $\mathrm{TFA}^{-}$ & 0.712 & 1.1 & $100 \%$ \\
& $\mathrm{AcO}^{-}$ & 0.816 & 1.9 & $114.6 \%$ \\
& $\mathrm{Cl}^{-}$ & 0.793 & 2.6 & $111.3 \%$ \\
Temporin $\mathrm{A}^{-}$ & $\mathrm{TFA}^{-}$ & 0.853 & 0.5 & $100 \%$ \\
& $\mathrm{AcO}^{-}$ & 0.895 & 2.7 & $104.9 \%$ \\
& $\mathrm{Cl}^{-}$ & 0.996 & 2.7 & $116.8 \%$
\end{tabular}


maximal relative content was found for LL-37 chloride (119.2\%). But mostly, the difference between chlorides and acetates in relation to the $\mathrm{TFA}^{-}$form oscillated around $10 \%$. These results indicate that there are no significant differences in peptide content that could affect the activity measured in biological assays.

\section{Antimicrobial activity}

All the tested peptides exhibited an antimicrobial activity; although entirely different (Table 3 ). To asses an overall activity of peptides, the mean MIC values were calculated. In general, the antistaphylococcal activity decreased in the order: CAMEL $>$ temporin A $>$ pexiganan $>$ citropin $1.1 \gg \mathrm{LL}-37$. The widest range of MIC values was found for LL-37 ( 2 to $>512 \mu \mathrm{g} / \mathrm{mL}$ ). It seems that in this case, two subpopulations, the resistant ( $>512 \mu \mathrm{g} / \mathrm{mL}$ ) and sensitive $(2-4 \mu \mathrm{g} / \mathrm{mL})$ strains could have been identified. Moreover, one intermediate strain was recognized, namely, ATCC $6538(64-128 \mu \mathrm{g} / \mathrm{mL})$. LL-37-sensitive subpopulation (only clinical isolates) was also susceptible to all AMPs used in this study. The low activity of LL-37 can be explained in terms of interplay of several mechanisms that $S$. aureus bacteria have evolved to resist the innate immune system. One of these are peptidases and proteases that are capable to hydrolyse AMPs; for example, the metalloprotease aureolysin and the serin protease V8 which exhibit high affinity towards LL-37 (Sieprawska-Lupa et al. 2004) (Kraus and Peschel 2008). The MIC ranges for peptides among strains are as follows: CAMEL, $\leq 0.25-8 \mu \mathrm{g} / \mathrm{mL}$; citropin $1.1,1-32 \mu \mathrm{g} / \mathrm{mL}$; pexiganan, $1-16 \mu \mathrm{g} / \mathrm{mL}$; and for temporin A, $2-8 \mu \mathrm{g} / \mathrm{mL}$. At first sight, it seems unclear how antistaphylococcal activity among the strains can differ between peptide salts. A better explanation can be provided by calculated mean MIC values (Table 5) and MIC distribution (Fig. 1). In case of all peptides, the lowest antimicrobial activity was found for trifluoroacetate salts. Moreover, MIC distribution for acetates and chlorides differs from that of trifluoroacetates. Importantly, distribution of MIC values for chlorides and acetates is shifted toward lower concentrations. Both peptide salts, the acetates and chlorides, seem to be more potent antimicrobials than trifluoroacetates; but, a decision on the superiority of one salt over the other cannot be taken. Interestingly, this conclusion could have been made owing to the significant number of the strains tested. In other words, the change in activity is strain-dependent, and only experiments carried out on different bacterial isolates can provide convincing results.
MIC distribution of peptides against all $S$. aureus strains used in this study is shown in Fig. 1.

\section{Hemolysis assay}

Peptides used in this study exhibited different profiles of hemolysis. We can classify AMPs by increasing hemolysis in the order: temporin A $<$ LL-37 < pexiganan TFA $^{-}$, $\left.\mathrm{Cl}^{-}\right)<$citropin $1.1<$ pexiganan $\left(\mathrm{AcO}^{-}\right)<$CAMEL. In fact, hemolysis of temporin A and LL-37 did not exceed 4\% even at their highest concentration of $256 \mu \mathrm{g} / \mathrm{mL}$. On account of their irrelevant toxicity towards human RBCs, those peptides have been excluded from further analysis of counterion effect on hemolysis. The results indicate that peptide trifluoroacetates are not as strongly hemolytic as it had been expected. Our results show that acetate counter-ions can substantially contribute to the hemolysis. For instance, the hemolysis of RBCs by pexiganan acetate ( $30.75 \%$ at $256 \mu \mathrm{g} /$ $\mathrm{mL}$ ) is substantially higher than that by both trifluoroacetate $(7.04 \%)$ and chloride $(8.51 \%)$. Moreover, similar conclusions can be applied to CAMEL. The chloride salts of the peptides seem to be the most suitable form owing to a noticeable increase in antistaphylococcal activity and moderate changes in hemolysis (Fig. 2).

\section{Cytotoxicity: MTT assay}

All the tested peptides exhibited a relatively high cytotoxicity against $\mathrm{HaCaT}$ cell line. The IC50 values ranged between 0.14 and $22.65 \mu \mathrm{g} / \mathrm{mL}$. Most of the determined IC50 values were lower than the mean MIC values, this being a serious drawback. In the case of CAMEL and citropin 1.1, counterion type had a little impact on cytotoxicity. With temporin A, the trifluoroacetate proved to be the least toxic, while the acetate was the most. Interestingly, for three peptides, citropin 1.1, LL-37, and pexiganan, the lowest cytotoxicity was found for the acetate salts. These results are not consistent with the hemolysis pattern. In fact, AMPs acetates (CAMEL, pexiganan) exhibited the highest toxicity against RBCs. The calculated selectivity index confirmed different selectivity of the peptide salts towards $S$. aureus strains (Table 6).

CAMEL was highly effective against all the tested strains with mean MIC value below $3.5 \mu \mathrm{g} / \mathrm{mL}$ for the three salts. According to the selectivity index, the most convenient would be the chloride. Unfortunately, its antimicrobial activity and toxicity against $\mathrm{HaCaT}$ cell line are similar, thus limiting its application. All citropin 1.1 salts exhibited high cytotoxicity in the MTT assay and high activity against $S$. aureus strains, both reference and clinical isolates. However, the selectivity index suggests a limited application of these 
Table 5 MIC values of the peptides $[\mu \mathrm{g} / \mathrm{mL}]$

\begin{tabular}{|c|c|c|c|c|c|c|c|c|c|c|c|c|c|c|c|}
\hline \multirow[t]{2}{*}{ Peptide and counter-ion } & \multicolumn{3}{|c|}{ CAMEL } & \multicolumn{3}{|c|}{ Citropin 1.1} & \multicolumn{3}{|l|}{ LL-37 } & \multicolumn{3}{|c|}{ Pexiganan } & \multicolumn{3}{|c|}{ Temporin A } \\
\hline & $\mathrm{TFA}^{-}$ & $\mathrm{AcO}^{-}$ & $\mathrm{Cl}^{-}$ & $\mathrm{TFA}^{-}$ & $\mathrm{AcO}^{-}$ & $\mathrm{Cl}^{-}$ & $\mathrm{TFA}^{-}$ & $\mathrm{AcO}^{-}$ & $\mathrm{Cl}^{-}$ & $\mathrm{TFA}^{-}$ & $\mathrm{AcO}^{-}$ & $\mathrm{Cl}^{-}$ & $\mathrm{TFA}^{-}$ & $\mathrm{AcO}^{-}$ & $\mathrm{Cl}^{-}$ \\
\hline \multicolumn{16}{|l|}{ S. aureus (29) } \\
\hline \multicolumn{16}{|l|}{ Reference (5) } \\
\hline ATCC 25923 & 8 & 8 & 2 & 32 & 16 & 16 & $>$ & $>$ & $>$ & 8 & 8 & 8 & 4 & 8 & 4 \\
\hline ATCC 6538 & 2 & $\leq$ & $\leq$ & 16 & 4 & 4 & 128 & 64 & 64 & 4 & 2 & 4 & 4 & 4 & 4 \\
\hline ATCC 6538/P & 4 & 1 & 1 & 16 & 8 & 8 & $>$ & $>$ & $>$ & 8 & 4 & 8 & 8 & 4 & 8 \\
\hline ATCC 9144 & 8 & 2 & 1 & 32 & 16 & 16 & $>$ & $>$ & $>$ & 8 & 8 & 8 & 8 & 8 & 8 \\
\hline ATCC 12598 & 4 & 2 & 1 & 16 & 8 & 8 & $>$ & $>$ & $>$ & 16 & 8 & 8 & 4 & 4 & 4 \\
\hline \multicolumn{16}{|l|}{ Clinical (24) } \\
\hline 001N (MRSA) & 4 & 2 & 2 & 16 & 16 & 16 & $>$ & $>$ & $>$ & 16 & 8 & 8 & 8 & 4 & 8 \\
\hline 001S (MRSA) & 4 & 4 & 2 & 16 & 16 & 16 & $>$ & $>$ & $>$ & 8 & 8 & 8 & 4 & 4 & 4 \\
\hline $002 \mathrm{~N}$ & 4 & 4 & $\leq$ & 16 & 16 & 16 & $>$ & $>$ & $>$ & 8 & 16 & 16 & 4 & 4 & 4 \\
\hline $002 \mathrm{~S}$ & 4 & 4 & 1 & 16 & 16 & 8 & $>$ & $>$ & $>$ & 16 & 16 & 16 & 4 & 4 & 4 \\
\hline 004N (MRSA) & 4 & 4 & 2 & 16 & 8 & 8 & $>$ & $>$ & $>$ & 8 & 4 & 8 & 4 & 4 & 4 \\
\hline $005 \mathrm{~S}$ & $\leq$ & $\leq$ & $\leq$ & 2 & 2 & 2 & 2 & 2 & 4 & 1 & 1 & 1 & 4 & 4 & 4 \\
\hline $013 \mathrm{~S}$ & $\leq$ & $\leq$ & $\leq$ & 2 & 2 & 2 & 2 & 4 & 2 & 1 & 1 & 1 & 4 & 4 & 4 \\
\hline 015N (MRSA) & 4 & 4 & 2 & 16 & 8 & 8 & $>$ & $>$ & $>$ & 16 & 4 & 4 & 8 & 4 & 8 \\
\hline 017N (MRSA) & 4 & 2 & 2 & 8 & 4 & 4 & $>$ & $>$ & $>$ & 4 & 2 & 2 & 8 & 4 & 8 \\
\hline 017S (MRSA) & 2 & 2 & 2 & 4 & 8 & 4 & $>$ & $>$ & $>$ & 4 & 2 & 2 & 8 & 4 & 8 \\
\hline 024N (MRSA) & $\leq$ & $\leq$ & $\leq$ & 2 & 2 & 2 & 2 & 4 & 2 & 1 & 1 & 1 & 4 & 4 & 4 \\
\hline $030 \mathrm{~N}$ & 4 & 4 & 4 & 16 & 16 & 16 & $>$ & $>$ & $>$ & 16 & 16 & 8 & 4 & 4 & 4 \\
\hline $033 \mathrm{~N}$ & 4 & 4 & 4 & 16 & 8 & 16 & $>$ & $>$ & $>$ & 16 & 8 & 16 & 4 & 2 & 4 \\
\hline $039 \mathrm{~N}$ & 4 & 4 & 4 & 16 & 8 & 16 & $>$ & $>$ & $>$ & 8 & 16 & 8 & 4 & 2 & 4 \\
\hline 043SC (MRSA) & 4 & 4 & 4 & 8 & 8 & 8 & $>$ & $>$ & $>$ & 8 & 4 & 4 & 8 & 4 & 8 \\
\hline $045 \mathrm{~N}$ & 4 & 4 & 4 & 16 & 16 & 16 & $>$ & $>$ & $>$ & 16 & 8 & 16 & 8 & 4 & 8 \\
\hline $048 \mathrm{~S}$ & 4 & 4 & 4 & 16 & 16 & 16 & $>$ & $>$ & $>$ & 16 & 16 & 16 & 4 & 4 & 4 \\
\hline 051N (MRSA) & 4 & 2 & 2 & 8 & 8 & 8 & $>$ & $>$ & $>$ & 8 & 8 & 8 & 8 & 4 & 8 \\
\hline $051 \mathrm{~S}$ & 2 & 2 & 2 & 4 & 4 & 4 & $>$ & $>$ & $>$ & 1 & 1 & 1 & 8 & 4 & 8 \\
\hline $053 \mathrm{~N}$ & 4 & 4 & 4 & 16 & 16 & 16 & $>$ & $>$ & $>$ & 8 & 8 & 8 & 8 & 4 & 4 \\
\hline $060 \mathrm{~S}$ & 2 & 1 & 1 & 2 & 1 & 2 & 2 & 2 & 2 & 2 & 1 & 1 & 4 & 2 & 4 \\
\hline K19N & 4 & 2 & 1 & 16 & 16 & 16 & $>$ & $>$ & $>$ & 8 & 16 & 16 & 8 & 8 & 8 \\
\hline $\mathrm{K} 46 \mathrm{~N}$ & 4 & 4 & 4 & 16 & 16 & 16 & $>$ & $>$ & $>$ & 8 & 8 & 8 & 8 & 4 & 8 \\
\hline K50S & 1 & 1 & 1 & 2 & 1 & 1 & 4 & 2 & 4 & 1 & 2 & 1 & 8 & 4 & 4 \\
\hline Mean value of MIC & $\leq 3.5$ & $\leq 2.8$ & $\leq 2.0$ & 13.0 & 10.0 & 10.0 & $>411$ & $>409$ & $>409$ & 8.4 & 7.1 & 7.4 & 5.9 & 4.2 & 5.7 \\
\hline
\end{tabular}

$\leq$ alone stands for $\mathrm{MIC} \leq 0.25 \mu \mathrm{g} / \mathrm{mL} ;>$ alone stands for MIC $>256 \mu \mathrm{g} / \mathrm{mL}$

peptides in the treatment of $S$. aureus infections. As previously stated, LL-37 exhibited low antistaphylococcal activity accompanied by a low hemolytic activity in all salt forms. Nevertheless, other studies on LL-37 (Johansson et al. 1998) provide evidence that the counter-ion may induce changes in peptide helical content and thus its antimicrobial activity against both Gram-positive Bacillus megaterium Bmll and Gram-negative Escherichia coli D21. Moreover, impact of trifluoroacetate and chloride on the peptide helicity proved to be entirely different. It has been stated that $\mathrm{TFA}^{-}$has greater ability to promote helix formation in LL-37 than does $\mathrm{Cl}^{-}$. In comparison to other forms $\left(\mathrm{Cl}^{-}\right.$and $\left.\mathrm{TFA}^{-}\right)$, pexiganan acetate showed the highest selectivity against $S$. aureus with selectivity index of 1.49. Interestingly, a formulation of pexiganan acetate was patented in 2015 by Dipexium Pharmaceuticals company (Nayan Desai 2013). The authors suggested that the acetate form is the most stable even during prolonged storage, and the formulation of this 
Fig. 1 MIC distribution of peptides
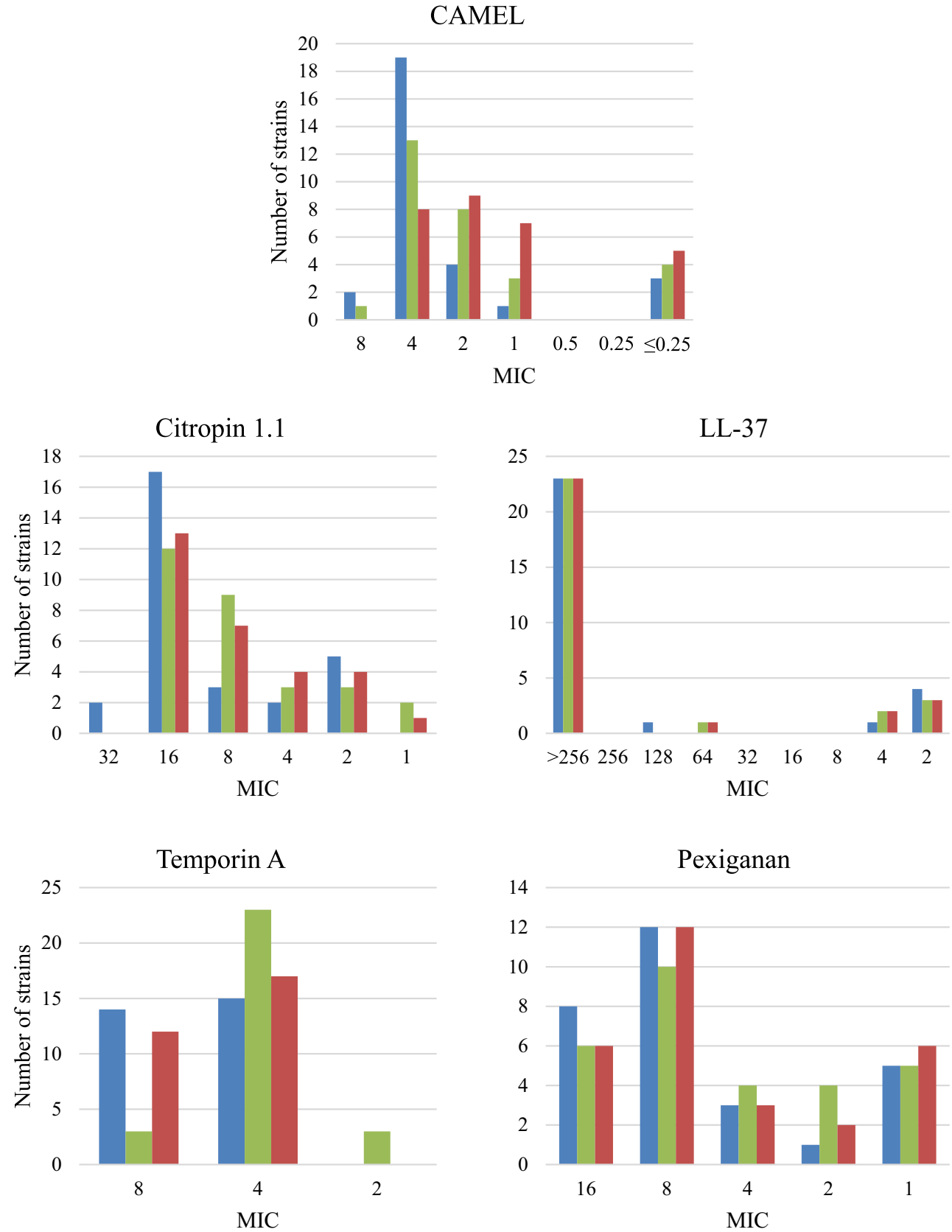

- TFA', $\square-\mathrm{AcO}^{-}, \square-\mathrm{Cl}^{-}$ peptide can be applied in the treatment of wound and skin infections often accompanied with presence of $S$. aureus. The MIC and IC50 values seem to confirm assumption that the pexiganan acetate is a promising candidate for further clinical tests. Moreover, this compound exhibited the lowest toxicity in the MTT assay and the hemolysis of RBCs at the mean MIC value was ignorable.
Temporin A showed a relatively high antimicrobial activity against $S$. aureus and almost undetectable hemolysis of RBCs. The calculated selectivity index showed that the greatest ratio of antistaphylococcal activity-to-cytotoxicity was found for TFA salts (1.36), whereas temporin A acetate and chloride revealed no selectivity $(0.22$ and 0.60 , respectively). 

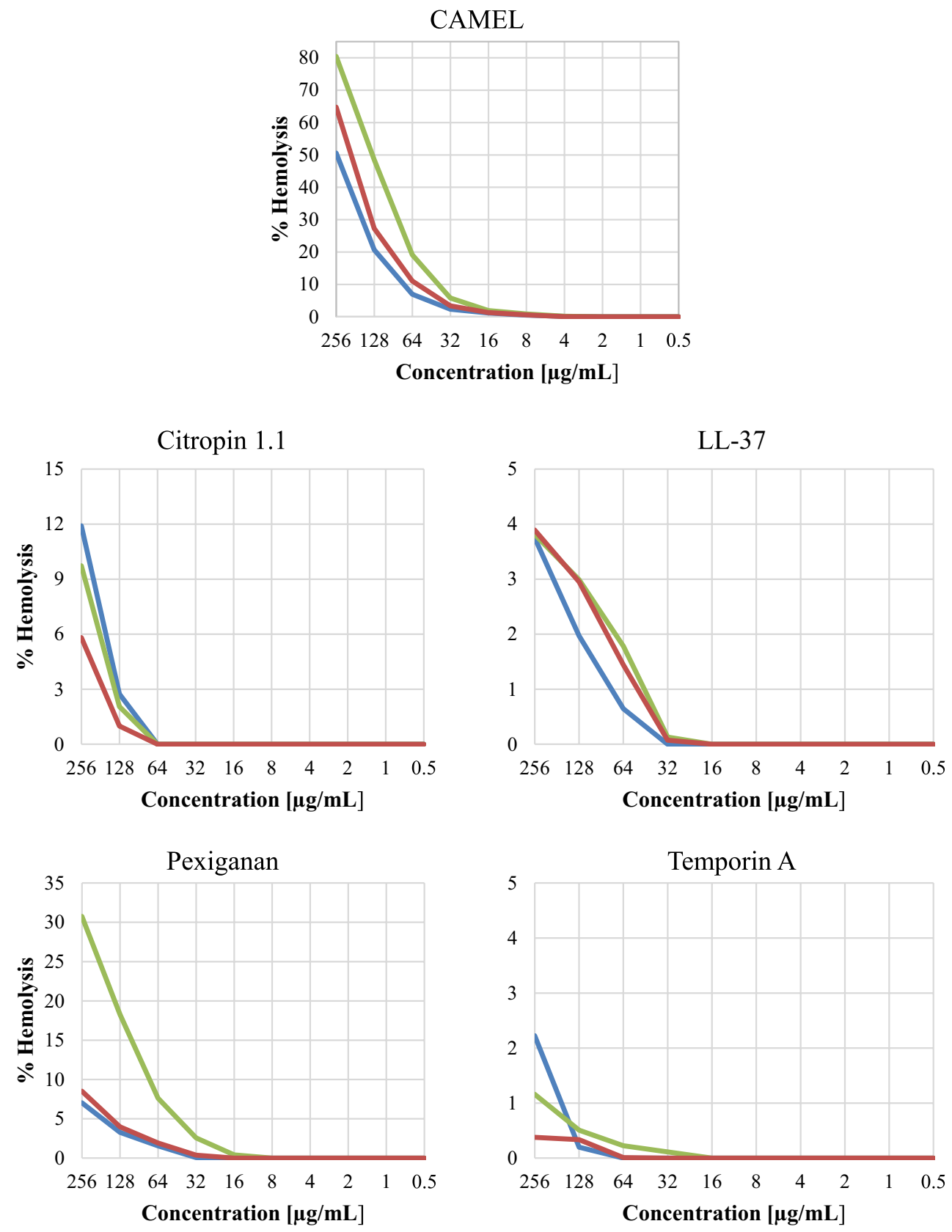

\section{- $\mathrm{TFA}^{-}, \square-\mathrm{AcO}^{-}, \square-\mathrm{Cl}^{-}$}

Fig. 2 Percentage of hemolysis of erythrocytes vs peptide concentration

\section{Conclusions}

Almost all the AMPs tested in this study exhibited a high activity against reference and clinical strains of $S$. aureus. Moreover, essential differences in antimicrobial, hemolytic activity, and cytotoxicity were found between the tested salts. In general, LL-37 showed weak antistaphylococcal properties, but three sensitive isolates were identified.
The greatest antistaphylococcal activity was noticed for CAMEL with a slight superiority of chloride form. On the other hand, this peptide showed the highest hemolytic activity among all the tested peptides and a relatively high cytotoxicity. Nonetheless, pexiganan acetate and temporin A trifluoroacetate exhibited the highest selectivity index among the tested salts. Surprisingly, pexiganan acetate is the one showing the highest hemolytic activity against 
Table 6 IC50 values and selectivity indexes of the peptides

\begin{tabular}{|c|c|c|c|}
\hline Peptide & $\mathrm{IC}_{50}$ & Mean MIC values & $\begin{array}{l}\text { Selectivity } \\
\text { index (IC50/ } \\
\text { MIC) }\end{array}$ \\
\hline \multicolumn{4}{|l|}{ CAMEL } \\
\hline $\mathrm{TFA}^{-}$ & 3.32 & $\leq 3.5$ & $\geq 0.95$ \\
\hline $\mathrm{AcO}^{-}$ & 2.72 & $\leq 2.8$ & $\geq 0.97$ \\
\hline $\mathrm{Cl}^{-}$ & 2.49 & $\leq 2.0$ & $\geq 1.25$ \\
\hline \multicolumn{4}{|c|}{ Citropin 1.1} \\
\hline $\mathrm{TFA}^{-}$ & 3.02 & 13.0 & 0.23 \\
\hline $\mathrm{AcO}^{-}$ & 4.37 & 10.0 & 0.44 \\
\hline $\mathrm{Cl}^{-}$ & 4.12 & 10.0 & 0.41 \\
\hline \multicolumn{4}{|l|}{ LL-37 } \\
\hline $\mathrm{TFA}^{-}$ & 11.75 & $>411$ & $<0.03$ \\
\hline $\mathrm{AcO}^{-}$ & 22.65 & $>409$ & $<0.06$ \\
\hline $\mathrm{Cl}^{-}$ & 4.26 & $>409$ & $<0.01$ \\
\hline \multicolumn{4}{|c|}{ Pexiganan } \\
\hline $\mathrm{TFA}^{-}$ & 1.05 & 8.4 & 0.13 \\
\hline $\mathrm{AcO}^{-}$ & 10.60 & 7.1 & 1.49 \\
\hline $\mathrm{Cl}^{-}$ & 0.14 & 7.4 & 0.02 \\
\hline \multicolumn{4}{|c|}{ Temporin A } \\
\hline $\mathrm{TFA}^{-}$ & 7.91 & 5.9 & 1.34 \\
\hline $\mathrm{AcO}^{-}$ & 0.92 & 4.2 & 0.22 \\
\hline $\mathrm{Cl}^{-}$ & 3.43 & 5.7 & 0.60 \\
\hline
\end{tabular}

Bold values are important in relation to the remaining results

human RBCs. The results obtained in this study suggest that there is no simple correlation between the type of counter-ion in the peptide and the biological activity. We believe that each case should be considered individually due to peptide-dependent differences between salts. Nevertheless, our findings undoubtedly support the thesis that the kind of the counter-ion is critical for biological properties of antimicrobial peptides.

Acknowledgements This study was supported by a Grant from the Polish National Science Centre (Project No. 2011/03/B/NZ7/00548). We wish to thank Professor Ryszard Piękoś for his invaluable help in preparing the manuscript.

Author contributions The manuscript was written through contributions of all authors. All authors have given approval to the final version of the manuscript.

\section{Compliance with ethical standards}

Conflict of interest The authors declare that they have no conflict of interest.

Informed consent All authors listed have contributed to conception, design, gathering, analysis, or interpretation of data, and have contributed to the writing and intellectual content of the article. All authors gave informed consent to the submission of this manuscript.
Ethical statement This article does not involve any studies with human participants or animals performed by any of the authors. The work concerning isolation of clinical strains was approved by the Ethics Committee of Medical University of Gdańsk.

Open Access This article is distributed under the terms of the Creative Commons Attribution 4.0 International License (http://creativecomm ons.org/licenses/by/4.0/), which permits unrestricted use, distribution, and reproduction in any medium, provided you give appropriate credit to the original author(s) and the source, provide a link to the Creative Commons license, and indicate if changes were made.

\section{References}

Andreu D, Ubach J, Boman A et al (1992) Shortened cecropin A-melittin hybrids. Significant size reduction retains potent antibiotic activity. FEBS Lett 296:190-194

Andrushchenko VV, Vogel HJ, Prenner EJ (2007) Optimization of the hydrochloric acid concentration used for trifluoroacetate removal from synthetic peptides. J Pept Sci 13:37-43. https:// doi.org/10.1002/psc.793

Avrahami D, Shai Y (2004) A new group of antifungal and antibacterial lipopeptides derived from non-membrane active peptides conjugated to palmitic acid. J Biol Chem 279:12277-12285. https://doi.org/10.1074/jbc.M312260200

Blondelle SE, Ostresh JM, Houghten RA, Pérez-Payá E (1995) Induced conformational states of amphipathic peptides in aqueous/lipid environments. Biophys J 68:351-359. https://doi. org/10.1016/S0006-3495(95)80194-3

Chandrudu S, Simerska P, Toth I (2013) Chemical methods for peptide and protein production. Molecules 18:4373-4388. https://doi. org/10.3390/molecules 18044373

Cinelli S, Spinozzi F, Itri R et al (2001) Structural characterization of the $\mathrm{pH}$-denatured states of ferricytochrome-c by synchrotron small angle X-ray scattering. Biophys J 81:3522-3533. https://doi. org/10.1016/S0006-3495(01)75983-8

CLSI (2012) Methods for dilution antimicrobial susceptibility tests for bacteria that grow aerobically. Approved standard, 9th edn. CLSI document M07-A9. Clinical and Laboratory Standards Institute, Wayne, PA

Cornish J, Callon KE, Lin CQ et al (1999) Trifluoroacetate, a contaminant in purified proteins, inhibits proliferation of osteoblasts and chondrocytes. Am J Physiol 277:E779-E783

Dawgul M, Baranska-Rybak W, Piechowicz L et al (2016) The antistaphylococcal activity of citropin 1.1 and temporin a against planktonic cells and biofilms formed by isolates from patients with atopic dermatitis: an assessment of their potential to induce microbial resistance compared to conventional antimicr. Pharmaceuticals. https://doi.org/10.3390/ph9020030

Fields GB, Noble RL (1990) Solid phase peptide synthesis utilizing 9-fluorenylmethoxycarbonyl amino acids. Int J Pept Protein Res 35:161-214

Gaussier H, Morency H, Lavoie MC, Subirade M (2002) Replacement of trifluoroacetic acid with $\mathrm{HCl}$ in the hydrophobic purification steps of pediocin PA-1: a structural effect. Appl Environ Microbiol 68:4803-4808. https://doi.org/10.1128/AEM.68.10.4803 $-4808.2002$

Ge Y, MacDonald DL, Holroyd KJ et al (1999) In vitro antibacterial properties of pexiganan, an analog of magainin. Antimicrob Agents Chemother 43:782-788

ICH (2005) Validation of analytical procedures : text and methodology Q2 (R1). In: International Conference on Harmonization. pp 1-13 
Johansson J, Gudmundsson GH, Rottenberg ME et al (1998) Conformation-dependent antibacterial activity of the naturally occurring human peptide LL-37. J Biol Chem 273:3718-3724. https://doi. org/10.1074/JBC.273.6.3718

Kraus D, Peschel A (2008) Staphylococcus aureus evasion of innate antimicrobial defense. Future Microbiol 3:437-451. https://doi. org/10.2217/17460913.3.4.437

Kuipers BJH, Gruppen H (2007) Prediction of molar extinction coefficients of proteins and peptides using uv absorption of the constituent amino acids at $214 \mathrm{~nm}$ to enable quantitative reverse phase high-performance liquid chromatography-mass spectrometry analysis. J Agric Food Chem 55:5445-5451. https://doi. org/10.1021/jf0703371

Larrick JW, Hirata M, Zhong J, Wright SC (1995) Anti-microbial activity of human CAP18 peptides. Immunotechnology 1:65-72

Mäde V, Els-Heindl S, Beck-Sickinger AG (2014) Automated solidphase peptide synthesis to obtain therapeutic peptides. Beilstein J Org Chem 10:1197-1212. https://doi.org/10.3762/bjoc.10.118

Mansour SC, Pena OM, Hancock RE (2014) Host defense peptides: front-line immunomodulators. Trends Immunol 35:443-450. http s://doi.org/10.1016/j.it.2014.07.004

Mohamed MF, Abdelkhalek A, Seleem MN (2016) Evaluation of short synthetic antimicrobial peptides for treatment of drug-resistant and intracellular Staphylococcus aureus. Sci Rep 6:29707. http s://doi.org/10.1038/srep29707

Nayan Desai (2013) Stable pexiganan formulation. Patent: US8530409 B1
Rizzolo F, Testa C, Lambardi D et al (2011) Conventional and microwave-assisted SPPS approach: a comparative synthesis of PTHrP(1-34)NH2. J Pept Sci 17:708-714. https://doi.org/10.1002 /psc. 1395

Roux S, Zékri E, Rousseau B et al (2008) Elimination and exchange of trifluoroacetate counter-ion from cationic peptides: a critical evaluation of different approaches. J Pept Sci 14:354-359. http s://doi.org/10.1002/psc.951

Sieprawska-Lupa M, Mydel P, Krawczyk K et al (2004) Degradation of human antimicrobial peptide LL-37 by Staphylococcus aureusderived proteinases. Antimicrob Agents Chemother 48:46734679. https://doi.org/10.1128/AAC.48.12.4673-4679.2004

Sikora K, Neubauer D, Jaśkiewicz M, Kamysz W (2017) Citropin 1.1 trifluoroacetate to chloride counter-ion exchange in hcl-saturated organic solutions: an alternative approach. Int J Pept Res. https:// doi.org/10.1007/s10989-017-9611-7

Simmaco M, Mignogna G, Canofeni S et al (1996) Temporins, antimicrobial peptides from the European red frog Rana temporaria. Eur J Biochem 242:788-792

Subirós-Funosas R, Prohens R, Barbas R et al (2009) Oxyma: an efficient additive for peptide synthesis to replace the benzotriazolebased HOBt and HOAt with a lower risk of explosion. Chem a Eur J 15:9394-9403. https://doi.org/10.1002/chem.200900614

Wegener KL, Wabnitz PA, Carver JA et al (1999) Host defence peptides from the skin glands of the Australian blue mountains treefrog Litoria citropa. Solution structure of the antibacterial peptide citropin 1.1. Eur J Biochem 265:627-637 